\title{
EVALUATION OF ELECTRICAL IMPEDANCE SPECTROSCOPY FOR CERVICAL INTRAEPITHELIAL LESIONS DETECTION
}

\author{
Germán Olarte Echeverri ${ }^{1}$ \\ William Aristizábal Botero² \\ Paula Andrea Gallego Sánchez ${ }^{3}$
}

\begin{abstract}
Objective: To evaluate the diagnostic accuracy of electrical impedance spectroscopy (EIS) in detection of pre-invasive cervical lesions. Design: Cross-sectional study of diagnostic validity carried out with 265 women between 15 and 55 years with abnormal pap smear report, referred to colposcopy, who were evaluated between January 2008 and June 2010 in the Cervical Pathology and Colposcopy Network in the Departments of Caldas and Risaralda (Colombia). Measurements of electrical impedance spectroscopy of the cervix were made, new pap smear samples were taken, colposcopic examination and colposcopically directed biopsies were performed. Results: The evaluated parameters were resistivity of the extracellular space $(R)$, resistivity of the intracellular space $(S)$, cell membrane capacitance $(\mathrm{Cm})$ and characteristic frequency $(\mathrm{Fc})$. The results obtained for $\mathrm{R}$ parameter were: in squamous normal tissue $21.27+/-16.48(\Omega$ $\mathrm{m})$; in high-grade lesions $4.28+/-2.28(\Omega-\mathrm{m})$; and in low-grade lesions $10.1+/-4.59(\Omega-\mathrm{m})$, showing a decrease of $\mathrm{R}$ in neoplastic tissue compared to normal tissue. The sensitivity of the EIS was 0.88 for high grade lesions and 0.71 for low grade lesions. The area under the ROC curves for high grade lesions / normal epithelium was 0.96, for low grade lesions/ normal epithelium was 0.76 and for high
\end{abstract}

grade/low grade was 0.90 . Conclusions: This study established that EIS is a useful technique for detection and characterization of cervical intraepithelial lesions, with diagnostic precision greater than $75 \%$, with sensitivity and specificity over $69 \%$, with an acceptable positive predictive value and a negative predictive value close to $90 \%$.

Palabras clave: electrical impedance, intraepithelial lesion, cervical cancer.

\section{EVALUACIÓN DE LA ESPECTROSCOPIA DE IMPEDANCIA ELÉCTRICA PARA LA DETECCIÓN DE LESIONES INTRAEPITELIALES DEL CUELLO UTERINO}

\section{RESUMEN}

Objetivo: Evaluar la precisión diagnóstica de la espectroscopia de impedancia eléctrica (EIE) en la detección de lesiones preinvasoras del cuello uterino. Diseño: Estudio de validez diagnóstica ensamblado en un estudio de corte transversal realizado en 265 mujeres entre los 15 y 55 años, con reporte de citología anormal, referidas a colposcopia, evaluadas entre enero de 2008 y junio de 2010 en la red de patología cervical y

\footnotetext{
${ }^{1}$ Médico y Cirujano, Ginecólogo-Oncólogo. Investigador U de Caldas. Manizales, Colombia. golarte72@hotmail.com 2 Magíster, Ingeniero electricista, DEA en bioingeniería. Investigador U de Caldas. Manizales, Colombia. william. aristizabal@ucaldas.edu.co

3 Médico y Cirujano, Ginecóloga y Obstetra, Ginecóloga-Oncóloga. Investigadora U de Caldas. Manizales, Colombia. paula.gallego@ucaldas.edu.co
} 
colposcopia en los departamentos de Caldas y Risaralda (Colombia). Se realizaron lecturas de espectroscopia de impedancia eléctrica del cuello uterino, nueva toma de citología, colposcopia y biopsias dirigidas. Resultados: Los parámetros evaluados fueron la resistividad del espacio extracelular (R), la resistividad del espacio intracelular (S), la capacitancia de la membrana celular $(\mathrm{Cm})$ y la frecuencia característica $(\mathrm{Fc})$. Los resultados obtenidos para la variable $R$ fueron: en tejidos escamosos normales de $21,27+/-16,48(\Omega-\mathrm{m})$, en lesiones de alto grado $4,28+/-2,28(\Omega-\mathrm{m})$ y en lesiones de bajo grado $10,1+/-4,59(\Omega-m)$, evidenciando una disminución de $\mathrm{R}$ en los tejidos lesionados respecto a los normales. La sensibilidad de la

\section{INTRODUCTION}

In recent years there has been a decrease of cervical cancer in developed countries due to the introduction of pap smear as a screening method $(1,2)$. However, in developing countries these early detection programs have not been equally effective due to the lack of political will to implement screening detection and control programs of this disease in an organized manner. These programs, based on pap smear as the screening method have failed, among other things, because of poor quality pap smear in both sampling and interpreting results which affect its sensitivity, calculated in $58 \%$ (3) for developed countries and in 30\% for developing countries (4). Currently the incidence of cervical cancer continues to increase in Latin America (5). In Colombia, the latest reported rate for 2003-2004 was 36.8 per 100,000 women (6) and the adjusted rate of mortality from this cause in 2002 was 18.2 per 100,000 women (7). Therefore, cervical cancer should be considered as a public health problem which requires highly effective screening techniques to detect pre-invasive lesions, and to decrease morbidity and mortality caused by this disease $(1,8-11)$.
EIE fue de 0,88 para lesiones de alto grado y de 0,71 para lesiones de bajo grado. El área bajo las curvas COR para lesiones de alto grado/ epitelio normal fue de 0,96; lesiones de bajo grado/epitelio normal 0,76 y lesión alto grado/ bajo grado 0,90. Conclusiones: Este estudio permitió establecer que la EIE es una técnica útil para la detección y caracterización de lesiones intraepiteliales del cuello uterino, con una precisión diagnóstica mayor al $75 \%$, con sensibilidad y especificidad superiores al $69 \%$, un valor predictivo positivo aceptable y un valor predictivo negativo, cercano al $90 \%$.

Key words: impedancia eléctrica, lesiones intraepiteliales, cáncer cervical.

To improve sensitivity in intraepithelial lesions and invasive cancer detection, new technologies such as liquid-based cytology (12), visual inspection methods with acetic acid and lugol's iodine (VIA, VILI) (13-18), electrical impedance spectroscopy (19-24) and optical fluorescence spectroscopy $(25,26)$ have permitted the achievement of diagnostic sensitivity greater than $70 \%$.

Electrical impedance spectroscopy is a technique with similar sensitivity and specificity to other detection methods of cervical intraepithelial lesions (20-22). It is a procedure performed in real time, which gets an immediate diagnosis which permits the implementation of the "see and treat methodology" in a single visit (27), and can be proposed as a useful tool for large populations diagnosis in developing countries.

EIS can noninvasively evaluate the shape, internal organization and structure of the tissue cells (19). Applying alternating current on the order of microamps on the tissue and measuring the potential difference between two points, it is possible to calculate the transfer impedance of the tissue (ratio between measured potential 
difference and current applied). With this impedance and a Debye's equivalent circuit, parameters characterizing the tissue can be found: $\mathrm{R}$ (resistivity of the extracellular space), $\mathrm{S}$ (resistivity of the intracellular space), $\mathrm{Cm}$ (cell membrane capacitance) and Fc (characteristic frequency).

This technique has been developed in the Medical Physics Department at Sheffield University (England) by Brown and colleagues, with application in pre-invasive cervical lesions. In Australia, Coppleson and colleagues have carried out works using a combination of electrical impedance spectroscopy and optical fluorescence (28). In Colombia, the Cervical Cancer and Breast Cancer Research Group at Caldas University, has reported results found in its population for intraepithelial lesions and invasive cervical cancer $(23,24)$.

The aim of this study was to evaluate the diagnostic accuracy of EIS as a tool for detecting pre-invasive cervical lesions.

\section{METHODS}

For the present study 265 patients with abnormal cytology report, admitted to the Cervical Cancer and Breast Cancer Program at Caldas University in the Manizales headquarters in Colombia were evaluated, and in the units of the Cervical Pathology and Colposcopy Network from 8 municipalities in Central-western Colombian areas, between 2008 and 2010 whom, after signing informed consent, were performed EIS measurements, a new pap smear, colposcopic examination and colposcopic-directed biopsy in case of lesions.

From the 265 patients evaluated, 137 met the inclusion criteria: age between 15 and 55 years, abnormal cytology without intervention of the cervix in the previous 6 months.

The following steps were applied in the protocol: initial cleaning of the cervix with saline solution at $0.9 \%$, clockwise measurements of EIS on squamous tissue, pap smear sample, colposcopic examination with acetic acid at $4 \%$, and again EIS measurements, Schiller Lugol's iodine test and biopsies of the lesions found.

EIS measurements were made using a Mk 3.5 single channel tissue impedance meter built in the Medical Physics Department at Sheffield University and a tetrapolar probe of $5.5 \mathrm{~mm}$ in diameter, with four gold electrodes $(1 \mathrm{~mm}$ diameter) (19).

In each patient were made four EIS measures, one at the area of the lesion and three in areas where normal epithelium was observed under colposcopy. The result was 548 EIS curves; 101 were not included in this study because the measures were made on columnar epithelium and this tissue was not the objective of this research or because the probe moved during EIS measurements. As a result, only 447 measurements were considered, corresponding to 68 high-grade lesions, 69 low-grade lesions and 310 in normal squamous epithelium. The lesions were classified by colposcopy results and histopathology. Each one of these curves was processed in the Matlab® platform, using an adjustment program to a Cole-Cole equation to obtain the electrical parameters for tissue characterization (19).

In the statistical processing $W$ Shapiro-Wilk normality tests were applied to $R, S, F c$ parameters and Mann Whitney's (Wilcoxon) nonparametric tests were made on the means and medians of R, S, Cm and Fc. The Pearson correlation coefficient was calculated to assess the linear association between $R$ and $S$ variables using the Statgraphics Plus 5.1 software. The $\square$ SPSS software was used to obtain the receiver's operating characteristic (ROC) curves between pairs of the considered diagnoses: normal, low grade, high grade, taking into account the area under the curve as a measure of diagnostic accuracy. Two-way tables were used to calculate 
the positive and negative predictive values of EIS technique with histology as the reference standard.

\section{RESULTS}

447 EIS curves were used with the following diagnoses: 68 high grade lesions (CIN 2/3), 69 low-grade lesions (HPV / CIN1) and 310 normal squamous epithelium. 7 diagnoses of cervicitis and 2 of endocervical polyps were not included in the study. The statistical values of parameters $\mathrm{R}, \mathrm{S}, \mathrm{Cm}$ and $\mathrm{Fc}$ are shown in Table 1.

The W Shapiro-Wilk tests showed that frequency distributions of values $R, S$ and Fc did not adjust to normal distributions.

The $R$ variable values were: $21.27+/-16.48(\Omega$ $\mathrm{m})$ in normal squamous tissue, $10.10+/-4.59$ $(\Omega-\mathrm{m})$ in low-grade lesions and 4.28 +/- $2.28(\Omega$ $\mathrm{m})$ in high grade lesions which shows a decrease of $\mathrm{R}$ by a factor close to 5 for tissues with highgrade lesions and 2 for low-grade lesions.

$\mathrm{R}$ mean parameter obtained for normal tissue and high and low grade lesions, as well as the medians were compared. In all cases statistically significant differences, $p$-value $<0.001$ were found.

The $S$ parameter results were: $2.29+/-1.67(\Omega$ m) for normal tissue, $2.52+/-1.20(\Omega-\mathrm{m})$ for low-grade lesions and $5.68+/-5.39(\Omega-\mathrm{m})$ for high-grade lesions. An increase in the average $S$ parameter by a 2.5 factor between normal tissue and high-grade lesions, and by a 1.1 factor between normal tissue and low-grade lesion was observed. Statistically significant differences were found between the means of parameter $S$ measured in normal tissues and high grade lesions, and between high-grade lesions and low grade lesions, p-value $<0.001$. No statistically significant differences were found for this parameter between normal tissues and low-grade lesions, $\mathrm{p}$-value $=0.279$.
The Cm results were: $1.44+/-1.78(\mu \mathrm{F} / \mathrm{m})$ for normal tissue, $1.7+/-1.5(\mu \mathrm{F} / \mathrm{m})$ for low-grade lesions and $1.7+/-3.28(\mu \mathrm{F} / \mathrm{m})$ for high-grade lesions. No statistically significant differences were found either between the means of the parameter $\mathrm{Cm}$ for high-grade lesions and normal tissue, $\mathrm{p}$-value $=0.361$, or between the medians, $\mathrm{p}$-value $=0.057$. There were no differences between the means for low-grade lesions and normal tissue, $\mathrm{p}$-value $=0.26$ or between the medians, $p$-value $=0.38$ either. Similarly, when comparing means and medians between high-grade and low grade lesions, we found no statistically significant differences between the means, $\mathrm{p}$-value $=1.0$ and $\mathrm{p}$-value $=0.06$ between the medians.

The results for the characteristic frequency Fc were: $11.3+/-10(\mathrm{kHz})$ for normal tissue, $14.9+/-17.16(\mathrm{kHz})$ for low-grade lesions and $37.27+/-32.25(\mathrm{kHz})$ for high-grade lesions. Statistically significant differences were found between the means and between the medians for high grade lesions and normal tissue, p-values $<0.001$. Also, between the means and the medians for low-grade lesions and normal tissue p-values were $<0.05$. There were also statistically significant difference between high-grade and low grade lesions and between the mean and the medians, $\mathrm{p}$-values $<0.001$.

To assess the degree of linear association between the $R$ and $S$ variables was used the Pearson correlation coefficient using pooled data from normal squamous tissue, low-grade lesions and high-grade lesions. The result $\left(r^{2}=0.0409\right)$ reveals low linear association between these parameters. To Fc parameter was not applied this test because the relationship of $R, S$ and $C_{m}$ with $F_{C}$ is circuital and mathematically defined like $F_{C}=1 / 2 \pi C_{m}(R+S)$.

To make the two-way tables histology was taken as a reference and EIS was taken as an alternative technique. Graphs for sensitivity and specificity were constructed against electrical resistivity of the tissue and the intersection of two curves 
was taken as the cutoff point that separates each diagnostic group, as it was reported by Olarte et al. in 2007 (23), at this point, sensitivity and specificity are maximized. The cutoff for $R$ between normal squamous epithelium and low grade lesions was $11.5(\Omega-\mathrm{m})$, between normal squamous epithelium and high-grade lesions was $7.4(\Omega-\mathrm{m})$, and between low-grade lesions and high grade lesions was $6.01(\Omega-\mathrm{m})$.

EIS was found to have 0.88 sensitivity and 0.89 specificity to separate a high-grade lesion from a normal squamous epithelium, positive predictive value PPV $=65.2 \%$ and negative predictive value NPV $=97.2 \%$. To separate a low-grade lesion from a normal epithelium, the test has 0.71 sensitivity and 0.69 specificity, PPV $=34 \%$ and $\mathrm{NPV}=91.5 \%$; to separate low-grade lesions from high-grade lesions, the technique has 0.79 sensitivity and 0.78 specificity, PPV = $78 \%$ and NPV $=79 \%$ (see Table 2 ).

To measure the diagnostic accuracy of the EIS technique in the detection of cervical intraepithelial lesions, the receiver operating characteristics curves (ROC) between pairs of groups were obtained and the area under the curve was used as an indicator of diagnostic test accuracy. The area under the curve obtained with normal squamous tissue and high-grade lesions was 0.96 (Figure 1). The area under the curve obtained with normal squamous tissue and low grade lesions was 0.76 (Figure 2), and the curve obtained with high-grade lesions and low grade, area under the curve, was 0.90 (Figure 3).

Table 1. Measurements of parameters from tissues.

\begin{tabular}{|c|c|c|c|c|c|c|c|c|c|}
\hline & & \multicolumn{5}{|c|}{ Median and range } & \multicolumn{3}{|c|}{ Mean } \\
\hline & & Minim & $\begin{array}{c}25 \\
\text { Percentile }\end{array}$ & Median & $\begin{array}{c}75 \\
\text { Percentile }\end{array}$ & Maxim & Mean & SD & SE \\
\hline \multirow{4}{*}{$\begin{array}{c}\text { Normal } \\
\text { squamous } \\
\text { epithelium } \\
n=310 \\
\text { measurements }\end{array}$} & $\mathrm{R}(\Omega-\mathrm{m})$ & 5.06 & 10.1 & 15.98 & 26.57 & 97.17 & 21.27 & 16.48 & 0.94 \\
\hline & $S(\Omega-m)$ & 0.18 & 1.58 & 1.99 & 2.47 & 17.86 & 2.29 & 1.67 & 0.09 \\
\hline & $\mathrm{C}_{\mathrm{m}}(\mu \mathrm{F} / \mathrm{m})$ & 0.141 & 0.59 & 0.959 & 1.69 & 23.6 & 1.44 & 1.78 & 0.101 \\
\hline & $\mathrm{Fc}(\mathrm{KHz})$ & 0.60 & 4.37 & 7.81 & 15.38 & 66.70 & 11.3 & 10 & 0.57 \\
\hline \multirow{4}{*}{$\begin{array}{c}\text { Low grade } \\
\text { lesion (HPV/ } \\
\text { CIN1) } \\
n=69 \\
\text { measurements } \\
\end{array}$} & $\mathrm{R}(\Omega-\mathrm{m})$ & 5.1 & 6.32 & 8.7 & 12.81 & 25.96 & 10.1 & 4.59 & 0.55 \\
\hline & $S(\Omega-m)$ & 0.78 & 1.83 & 2.27 & 2.9 & 9.59 & 2.52 & 1.20 & 0.14 \\
\hline & $\mathrm{C}_{\mathrm{m}}(\mu \mathrm{F} / \mathrm{m})$ & 0.0593 & 0.779 & 1.02 & 2.14 & 7.76 & 1.7 & 1.5 & 0.181 \\
\hline & $\mathrm{Fc}(\mathrm{KHz})$ & 1.48 & 6.06 & 12.4 & 18.28 & 137.14 & 14.97 & 17.16 & 2.06 \\
\hline \multirow{4}{*}{$\begin{array}{c}\text { High grade } \\
\text { lesion } \\
(\mathrm{CIN} 2 / 3) \\
n=68 \\
\text { measurements }\end{array}$} & $\mathrm{R}(\Omega-\mathrm{m})$ & 1.26 & 2.56 & 3.878 & 5.6 & 9.74 & 4.28 & 2.28 & 0.28 \\
\hline & $S(\Omega-m)$ & 0.008 & 2.33 & 3.33 & 7.06 & 25.38 & 5.68 & 5.39 & 0.65 \\
\hline & $\mathrm{C}_{\mathrm{m}}(\mu \mathrm{F} / \mathrm{m})$ & 0.0794 & 0.298 & 0.706 & 2.2 & 25.2 & 1.7 & 3.28 & 0.398 \\
\hline & $\mathrm{Fc}(\mathrm{KHz})$ & 2.3 & 10.26 & 26.18 & 64.85 & 128.73 & 37.27 & 32.25 & 3.91 \\
\hline
\end{tabular}

$\mathrm{R}$ (extracellular resistivity), $\mathrm{S}$ (intracellular resistivity), $\mathrm{Cm}$ (membrane capacitance) and Fc (characteristic frequency). $\mathrm{R}$ and $\mathrm{S}$ are reported in $\Omega-\mathrm{m}, \mathrm{Cm}$ is reported in $\mu \mathrm{F} / \mathrm{m}$ and $\mathrm{Fc}$ is reported in $\mathrm{KHz}$. 
Table 2. Two-way table for sensitivity, specificity and predictive values of EIS compared to histological diagnosis.

CIN 2-3/Normal

Histological diagnosis

\begin{tabular}{|c|c|c|c|c|}
\hline & & + & - & \\
\hline EIS & + & 60 & 32 & 92 \\
\hline \multirow[t]{2}{*}{ Cutoff (7.4 $\Omega-\mathrm{m})$} & - & 8 & 278 & 286 \\
\hline & & 68 & 310 & 378 \\
\hline \multirow[t]{2}{*}{ HPV-CIN1/Normal } & & \multicolumn{3}{|c|}{ Histological diagnosis } \\
\hline & & + & - & \\
\hline \multirow{3}{*}{$\begin{array}{c}\text { EIS } \\
\text { Cutoff }(\mathbf{1 1 . 5} \Omega-\mathrm{m})\end{array}$} & + & 49 & 95 & 144 \\
\hline & - & 20 & 215 & 235 \\
\hline & & 69 & 310 & 379 \\
\hline \multirow[t]{2}{*}{ HPV-CIN1/CIN2-3 } & & \multicolumn{3}{|c|}{ Histological diagnosis } \\
\hline & & + & - & \\
\hline \multirow{3}{*}{$\begin{array}{c}\text { EIS } \\
\text { Cutoff }(6.01 \Omega-m)\end{array}$} & + & 54 & 15 & 69 \\
\hline & - & 14 & 54 & 68 \\
\hline & & 68 & 69 & 137 \\
\hline
\end{tabular}

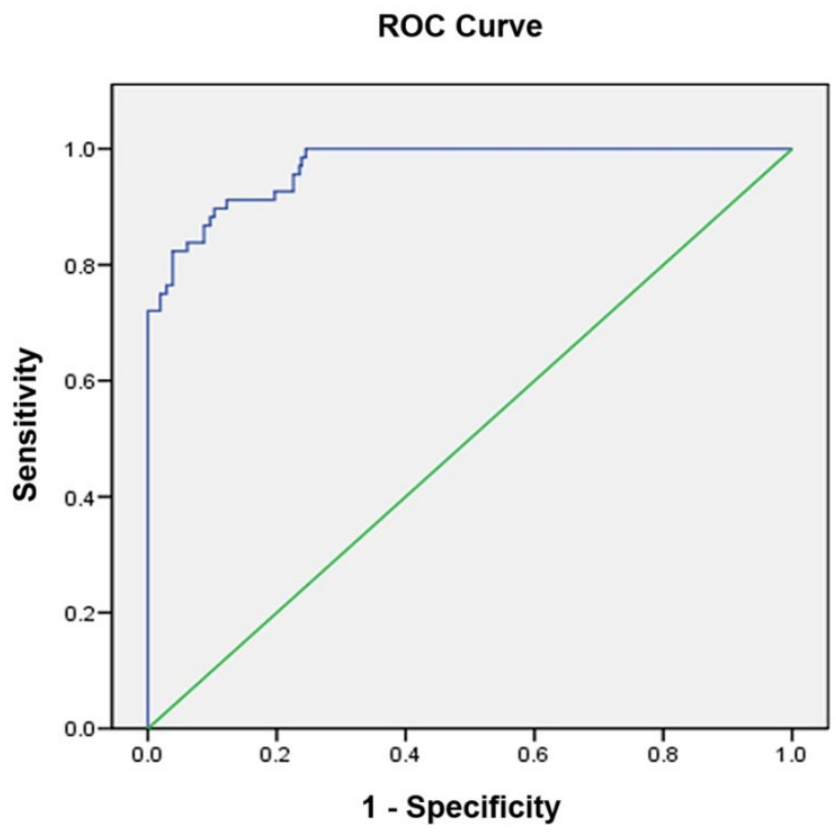

Figure 1. ROC curve using $R$ to separate normal squamous epithelium from CIN 2/3.

Area under curve 0.96 . 


\section{Biosalud}

Germán Olarte Echeverri, William Aristizábal Botero, Paula Andrea Gallego Sánchez

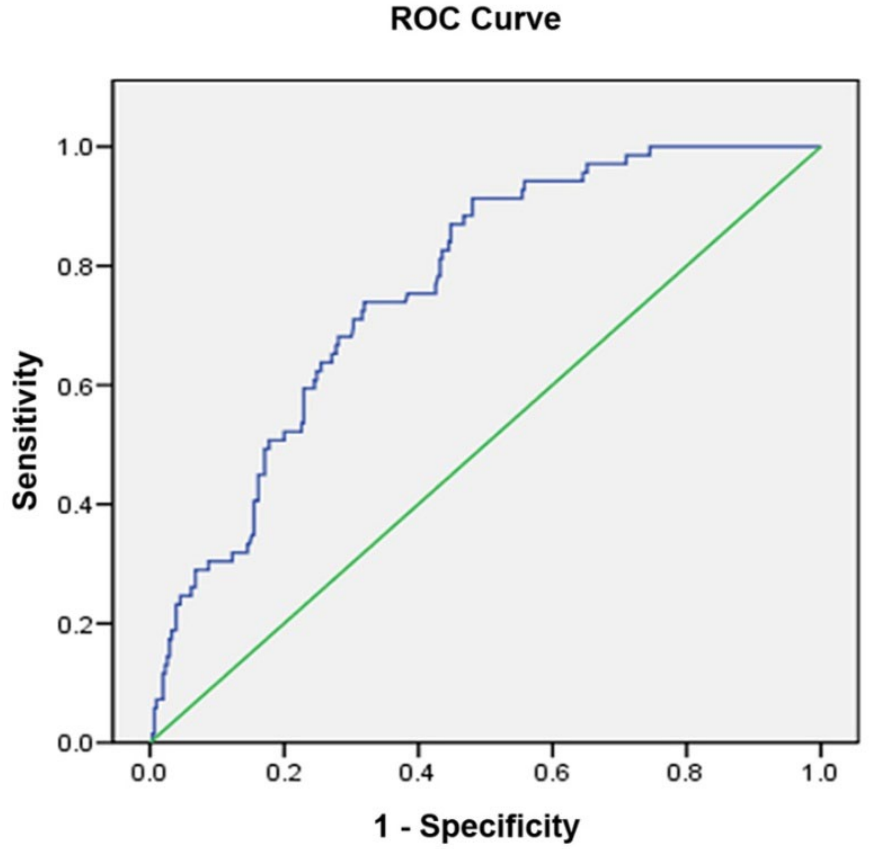

Figure 2. ROC curve using $\mathrm{R}$ to separate normal squamous epithelium from HPV/CIN 1. Area under curve 0.76 .

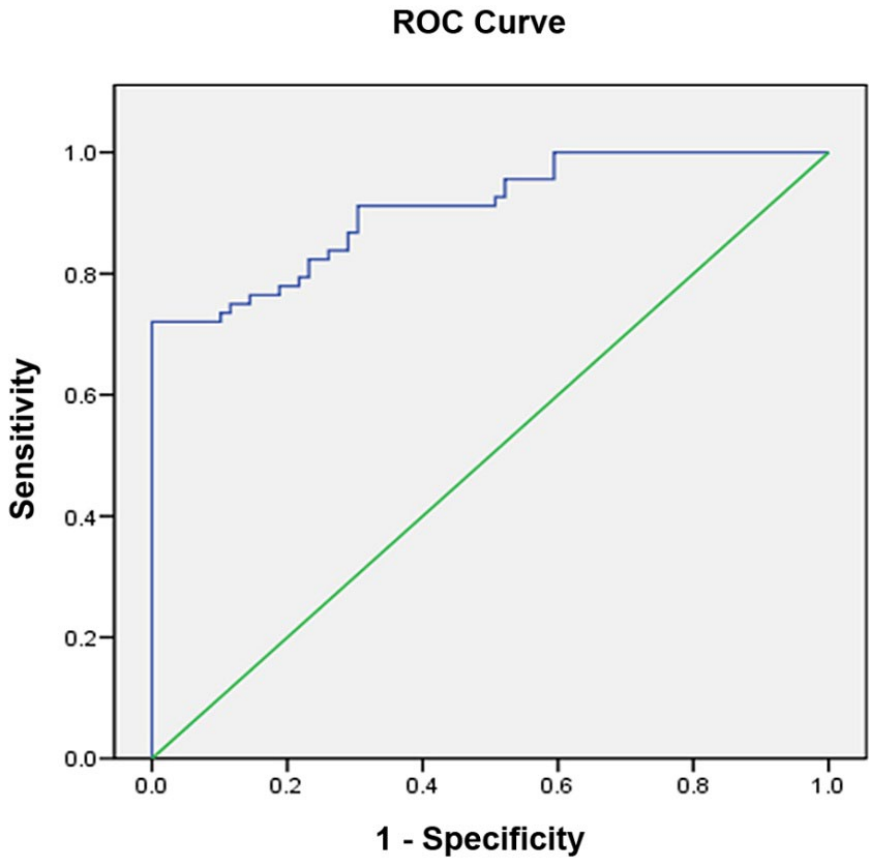

Figure 3. ROC curve using R to separate CIN 2/3 from HPV/CIN1.

Area under curve 0.90 . 


\section{DISCUSSION}

This study found that Debye's circuit model and Cole-Cole's fit equation are adequate for calculating the R, S, Cm and Fc electrical parameters and these parameters allow the characterization of normal and pathological squamous epithelial tissues; these findings had been already reported by several research groups $(19,20,23)$.

It was also found that parameter $\mathrm{R}$ reflects the electrical behavior of the extracellular space showing a decrease as the degree of lesion progresses from CIN 1 to CIN 2-3. This variation can be explained by the increase in the volume of extracellular space of abnormal tissues due to changes in the architectural arrangement of the multilayer squamous tissue.

TheS parameter increased according to the degree of lesion. The increase in intracellular resistivity can be explained because of the narrowing of the pathways for current flow in the cytoplasm, due to the increase in nuclear size and the nuclearcytoplasmic ratio when intraepithelial neoplasia is present. This condition has been reported widely in the literature (29).

The $\mathrm{Cm}$ parameter, related to the membrane capacitance, did not present statistically significant differences between normal tissues and lesions CIN1 and CIN 2-3, similar to the findings in previous studies by Brown et al. (19), Abdul et al. (21) and Olarte et al. (23). However, the $\mathrm{Fc}_{\mathrm{c}}$ parameter which is inversely related to the $C_{m}(R+S)$ product did show statistically significant difference and a progressive increase with the degree lesion, which coincides with other research groups' findings.

This study found that the EIS technique is a useful tool in the diagnosis of cervical intraepithelial lesions with sensitivity and specificity similar to currently used diagnostic techniques. In addition, the possibility to get real time diagnosis, decreasing anxiety of the patient and costs for multiple gynecological visits. The sensitivity found for separating high-grade lesions from normal squamous epithelium was 0.88 and for separating low-grade lesions from normal squamous epithelium was 0.83 ; these values did not differ from those reported by Brown et al. in 2000 (19), Abdul et al. in 2006 (21) and Olarte et al. in 2007 (23). It was also found that the sensitivity and specificity when comparing low-grade lesions with high-grade lesions were 0.79 and 0.78 and are consistent with the findings of other research groups (19$21,23)$.

The values of $\mathrm{R}$ were: $21.27+/-16.4(\Omega-\mathrm{m})$ for normal squamous tissue, $10.1+/-4.6(\Omega-\mathrm{m})$ for low-grade and $4.28+/-2.28(\Omega-m)$ for high grade. Which are similar to $23.87+/-14.86$, $11.12+/-8.49$ and $7.5+/-9.34(\Omega-\mathrm{m})$, reported by Abdul et al. in 2006 (21) for the tissues mentioned above. For the $S$ parameter values were: $2.29+/-1.6(\Omega-\mathrm{m})$ for normal tissue, 2.52 $+/-1.2(\Omega-\mathrm{m})$ for low-grade and $5.68+/-5.39$ $(\Omega-m)$ for high-grade with an increase in their value that matches with what was previously described. As far as the parameter $\mathrm{Cm}$ there were not statistically significant differences similar to those reported in other studies (19). The Fc also had a behavior of progressive increase as the lesion degree increased: $11.3+/-10(\mathrm{kHz})$ for normal squamous tissue, $14.97+/-17.6(\mathrm{kHz})$ for low-grade lesions and 32, $27+/-32.25(\mathrm{kHz})$ for high grade lesions, similar to those reported by Abdul et al. in 2006 (21).

From the studied parameters it was found that $R$ is the parameter that best discriminates between normal tissues and low and high grade intraepithelial lesions, which can be explained because of the increased volume of extracellular space; this increase can become up to 6 times higher in dysplastic tissues (29). The $S$ parameter related to the increase in nuclear size and the nuclear-cytoplasmic ratio is helpful to discriminate normal tissues and high grade lesions or between low grade and high grade lesions but not normal tissues and low grade 
lesions. The Fc that is function of $R, S$ and $C_{m}$ parameters is helpful to discriminate the three types of tissues.

\section{CONCLUSIONS}

This study permitted the establishment of EIS as a useful technique for the detection and characterization of cervical intraepithelial lesions with a diagnostic accuracy greater than $75 \%$, with sensitivity and specificity over $69 \%$, a predictive positive value between $34 \%$ and $78 \%$ and a negative predictive value close to $90 \%$. The latter is important in effective diagnosis tools which makes EIS an alternative, non-invasive, quick and inexpensive to diagnose these lesions which is useful in programs for developing countries where low cost, simple to implement methods not requiring highly trained staff and providing immediate results must be used.

\section{CONFLICT OF INTEREST STATEMENT}

We declare that we have no conflict of interest.

\section{ACKNOWLEDGMENTS}

This work was supported for Vicerrectoría de Investigaciones y Postgrados. Universidad de Caldas. Manizales, Colombia.

\section{REFERENCES}

1. Program for Appropiate Technology in Health PATH. Planning appropriate cervical cancer prevention programs. 2nd Ed.; 2000.

2. Vizcaíno AP, Moreno V, Bosh FX, Muñoz N, Barros-Dios XM, Borras J, et al. International trends in the incidence of cervical cancer: II. Squamous-cell carcinoma. Int J Cancer 2000; 86:429-435.

3. Acog Practice Bulletin. Clinical management guidelines for obstetrician-gynecologists. 2008; 112(6).

4. Nanda K, McCrory D, Myers E, Bastian L, Hasselblad V, Hickey J, et al. Accuracy of the papanicolaou test in screening for and follow-up of cervical cytologic abnormalities: a systematic review. Ann Intern Med 2000; 132(10):810-9.

5. Arrossi S, Sankaranarayanan R, Parkin DM. Incidence and mortality of cervical cancer in Latin America. Salud Pública Mex 2003; 45(Suppl 3):5306-5314.

6. Piñeros M, Ferlay J, Murillo R. Cancer incidence estimates at the national and district levels in Colombia. Salud Pública Mex 2006; 48(6):455-465.

7. Wiesner-Ceballos C, Murillo- Moreno RH, Piñeros-Petersen M, Tovar-Murillo SL, Cendales-Duarte R, Gutiérrez MC. Control del cáncer cervicouterino en Colombia: la perspectiva de los actores del sistema de salud. Rev Panam Salud Pública 2009; 25(1):1-8.

8. Cronje H.S. Screening for cervical cancer in the developing World. Best Pract Res Clin Obstet Gynaecol 2005; 19:517-529.

9. Lazcano-Ponce E, Alonso P, Ruiz-Moreno JA, Hernández-Ávila M. Recommendations for cervical cancer screening programs in developing countries. The need for equity and technological development. Salud Pública Mex 2003; 45(Suppl 3):S449-S462

10. Lazcano-Ponce $E$, Alonso $P$, Hernández-Ávila M. Nuevas alternativas de prevención secundaria del cáncer cervical. Salud Pública Mex 2007; 49:E32-E34.

11. Sankaranarayanan R, Madhukar A, Rajkumar R. Effective screening programmes for cervical cancer in low- and middle-income developing countries. Bull World Health Org 2001; 79:954-962.

12. Stein S. Thinprep versus the conventional papanicolaou test: a review of specimen adequacy, 
sensitivity, and cost-effectiveness. Prim Care Update Ob Gyns 2003; 10(6):310-313.

13. Goel A, Gandhi G, Batra S, Bhambhani S, Zutshi V, Sachdeva P. Visual inspection of the cervix with acetic acid for cervical intraepithelial lesions. Int J Gynaecol Obstet 2005; 88:25-30.

14. De Vuyst $H$, Claeys $P$, Njiru $S$, Muchiri $S$, Steyaert $S$, De Sutter $P$, et al. Comparison of pap smear, visual inspection with acetic acid, human papillomavirus DNA-PCR testing and cervicography. Int J Gynaecol Obstet 2005; 89:120-126.

15. Sankaranarayanan R, Nene BM, Dinshaw K, et al. Early detection of cervical cancer with visual inspection methods: a summary of completed and ongoing studies in India. Salud Pública Mex 2003; 45(Suppl 3):S399-S407.

16. Sankaranarayanan R, Wesley R, Thara S, Dhakad N, Chandralekha B, Sebastian P, et al. Test characteristics of visual inspection with $4 \%$ acetic acid (VIA) and Lugol's iodine (VILI) in cervical cancer screening in Kerala, India. Int J Cancer 2003; 106(3):404-408.

17. Basu PS, Sankaranarayanan R, Mandal R, Roy C, Das P, Choudhury D, et al. Visual inspection with acetic acid and cytology in the early detection of cervical neoplasia in Kolkata, India. Int J Gynecol Cancer 2003; 13(5):626-632.

18. University of Zimbawe/JHPIEGO Cervical Cancer Project. Visual inspection with acetic acid for cervical cancer screening test qualities in a primary-care setting. The Lancet $1999 ; 353: 869-873$.

19. Brown BH, Tidy JA, Boston K, Blackett AD, Smallwood RH, Sharp F. Relation between tissue structure and imposed electrical current flow in cervical neoplasia. The Lancet 2000; 355:892-895.

20. Abdul S, Brown B, Milnes P, Tidy J. A clinical study of the use of impedance spectroscopy in the detection of cervical intraepithelial neoplasia (CIN). Gynecol Oncol 2005; 99(3 Suppl 1):S64-S66.

21. Abdul S, Brown BH, Milnes P, Tidy JA. A clinical study of the use of impedance spectroscopy in the detection of cervical intraepithelial neoplasia (CIN). Int J Gynecol Cancer 2006; 16:1823-1832.

22. Balasubramani L, Brown B, Healey J, Tidy JA. The detection of cervical intraepithelial neoplasia by electrical impedance spectroscopy: The effects of acetic acid and tissue homogeneity. Gynecol Oncol 2009; 115:267-271.

23. Olarte G, Aristizábal W, Gallego PA, Rojas J, Botero BE, Osorio GF. Detección precoz de lesiones intraepiteliales del cuello uterino en mujeres de Caldas-Colombia mediante la técnica de espectroscopia de impedancia eléctrica. Rev Colomb Obstet Ginecol 2007; 58(1):13-20.

24. Olarte G, Aristizábal W, Osorio GF, Rojas J. Espectroscopía de impedancia eléctrica en cáncer invasivo del cuello uterino en mujeres de Caldas (Colombia), 2008-2009. Rev Colomb Obstet Ginecol 2010; 61(1):28-33.

25. Ramanujam N, Mitchell MF, Mahadevan A, Thomsen SL, Staerkel G, Malpica A, et al. Cervical precancer detection using a multivariate statistical, algorithm based on laser induced fluorescence at multiple excitation wavelengths. Photochem Photobiol 1996; 64(4):720-735.

26. Ramanujam N, Mitchell MF, Mahadevan A, Thomsen SL, Warren S, Silva E, et al. In vivo diagnosis of cervical intraepithelial neoplasia using $337 \mathrm{~nm}$ - excited laser induced fluorescence. Proc. Natl. Acad. Sci. USA 1994; 91:10193-10197.

27. Royal Thai College of Obstetricians and Gynaecologists (RTCOG) and the JHPIEGO Corporation Cervical Cancer Prevention Group. Safety, acceptability, and feasibility of a single-visit approach to cervicalcancer prevention in rural Thailand: a demonstration project. Lancet 2003; 361:814-820.

28. Coppleson M, Reid BI, Skladnev VN, Dalrymple JC. An electronic approach to the detection of precancer and cancer of the uterine cervix: a preliminary evaluation of Polarprobe. Int J Gynaecol Cancer 1994; 4:79-83.

29. Walker DC, Brown BH, Blackett AD, Tidy J, Smallwood RH. A study of the morphological parameters of cervical squamous epithelium. Physio Meas 2003; 24:121-35. 